\title{
HISTIDINE AS THE FUNCTIONAL GROUP FOR A CHELATING ION EXCHANGER
}

\section{CHUEN-YING LIU}

Department of Chemistry, National Taiwan University, Taipei 107 (Taiwan)

(Received 21st March 1986)

\section{SUMMARY}

In the chelating ion exchanger synthesized, the amino group of histidine is attached chemically via the azide method to the carboxyl group of Amberlite IRC-50. A flow system based on a spectrophotometric detector, with 4-(2-pyridylazo)resorcinol as reagent, is described for fast assays of eluted cations. The $\mathrm{pH}$ dependence of the metal extraction is reported for $\mathrm{Ag}(\mathrm{I}), \mathrm{Au}(\mathrm{III}), \mathrm{Cu}(\mathrm{II}), \mathrm{Fe}(\mathrm{III}), \mathrm{Hg}(\mathrm{II}), \mathrm{Ni}(\mathrm{II})$ and $\mathrm{Zn}(\mathrm{II})$ ions. The resin exhibits no affinity for the alkali or alkaline earth metals. The uptake of traces of the specified elements from synthetic samples by a short $(90 \mathrm{~mm})$ column of the histidinecontaining resin was in the range $94-100 \%$ and the retained metals were readily eluted by means of $2 \mathrm{M}$ hydrochloric or hydrobromic acid. In column operation, mercury was quantitatively recovered even in the presence of large excesses of various ligands. The recoveries of the trace metals were good at the usual $\mathrm{pH}$ of natural waters.

Ion exchangers have been widely used for the preconcentration of metal ions from various matrices [1]. In particular, chelating resins are valuable because of their selectivity for a large number of metals over the alkali and alkaline earth metals. Imidazole derivatives play an important role in biological systems, e.g., in several hydrolases [2] and hemoproteins [3-5]. Therefore, several studies have been published about imidazole-containing polymers. Polymers with chemically bound imidazole groups are of interest from different points of view. As weakly basic polymers, or after quaternization as polymers with strongly basic properties, they can be applied as ion exchangers $[6,7]$. They have also been tested as catalysts in the hydrolysis of esters and used as ligands for complexing metallic ions [8]. Histidine [2-amino-3-(4'-imidazolyl)-propanoic acid] contains four different functional groups which are potential sites of coordination to metal ions, i.e., the charged carboxyl group, the uncharged amino group, and the two nitrogens in the imidazole ring. A marked change in their chelating behavior and properties would be expected on introducing more functional groups into the molecule. In spite of the voluminous research on metal/histidine complexes [9], there are few reports about histidine-containing polymers, especially with regard to their chelating properties. It was therefore thought to be of interest to synthesize a histidine-containing polymer and to test its properties in an ion exchanger. 
In this paper, a new chelating resin containing histidine groups, prepared from the common cation-exchange resin, Amberlite IRC-50, is reported. The complexation of various metal ions and the extractive properties of the resin are described.

\section{EXPERIMENTAL}

\section{Apparatus and reagents}

The flow system for the detection of transition metal ions is shown in Fig. 1. The system consisted of two Milton-Roy pumps (Model 396 Simplex), a Cheminert rotary injection valve (Model R-6031SV-K) equipped with a 100- $\mu$ l sample loop, a polyhistidine resin column $(90 \times 4 \mathrm{~mm}$ i.d. $)$, a LDC/ Milton Roy Spectromonitor D variable-wavelength detector and a Yokogawa automatic recorder. The flow rate was $0.53 \mathrm{ml} \mathrm{min}^{-1}$ for pump 1 and $0.07 \mathrm{ml}$ $\min ^{-1}$ for pump 2.

4-(2-Pyridylazo)resorcinol (PAR) was used for the detection of metal ions. The aqueous reagent contained $2 \times 10^{-4} \mathrm{M}$ PAR, $1 \mathrm{M}$ ammonium acetate and ammonia solution $(d=0.88)\left(15 \mathrm{ml} \mathrm{l}^{-1}\right)$. It was found advisable to degas the reagent and store it under nitrogen to prevent oxidation. Table 1 lists the absorption maxima for several cation complexes.

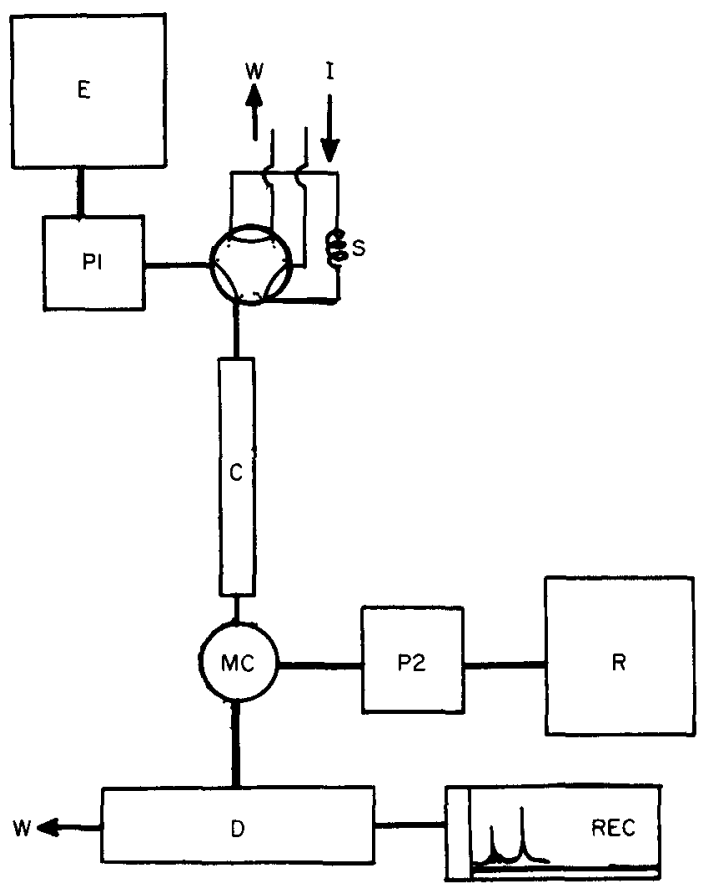

Fig. 1. Schematic diagram of the flow system for the determination of transition metals: E, eluent tank; P1, P2, pumps; I, injection; S, sample loop; C, resin column; MC, mixing chamber; $R$, reagent reservoir; $D$, detector; Rec, recorder; $W$, waste. 
TABLE 1

Absorption maxima for complexes of metal cations with PAR

\begin{tabular}{llllllll}
\hline Complex metal & $\mathrm{Cu}$ & $\mathrm{Pb}$ & $\mathrm{Ni}$ & $\mathrm{Co}$ & $\mathrm{Fe}$ & $\mathrm{U}$ & $\mathrm{Hg}$ \\
$\lambda_{\max }(\mathrm{nm})$ & 507 & 529 & 501 & 530 & 510 & $\mathbf{5 2 9}$ & $\mathbf{5 2 7 . 5}$ \\
\hline
\end{tabular}

Amberlite IRC-50 (16-30 mesh; Rohm and Haas) was extracted with methanol, dried, ground and sieved. The 30-60 mesh and 60-100-mesh fractions were washed with $12 \mathrm{M}$ hydrochloric acid, water and acetone successively, and used in the synthesis.

Synthesis of the histidine-containing resin

The derivatized resin was prepared by the following reaction sequence [10].

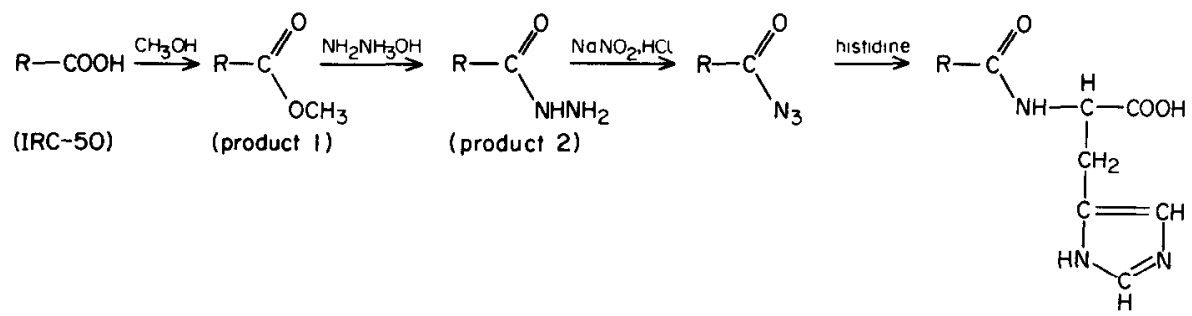

To $60 \mathrm{~g}$ of the pre-treated Amberlite IRC- 50 resin was added $600 \mathrm{ml}$ of methanol containing $15 \mathrm{ml}$ of $18 \mathrm{M}$ sulfuric acid as catalyst. The resulting mixture was refluxed at $70^{\circ} \mathrm{C}$ for $20 \mathrm{~h}$. The product was cooled to room temperature and then collected by filtration under suction and washed sequentially with water and methanol until no sulfate ion appeared in the filtrate. The above procedures were repeated to obtain a higher yield. Product 1 was mixed with $400 \mathrm{ml}$ of methanol. Then $25 \mathrm{ml}$ of hydrazine hydrate was added dropwise and the mixture was left to react at room temperature for $30 \mathrm{~h}$. The product was washed with water until no hydrazine appeared in the filtrate. To product 2 was added $500 \mathrm{ml}$ of $0.42 \mathrm{M}$ hydrochloric acid. While the mixture was constantly agitated in a freezing mixture of salt and ice, a solution of $100 \mathrm{ml}$ of $0.2 \mathrm{M}$ sodium nitrite was added dropwise. After the addition was complete, the mixture was stirred at $0^{\circ} \mathrm{C}$ for $30 \mathrm{~min}$, and $33 \mathrm{~g}$ of L-histidine was added. Then $50 \mathrm{ml}$ of triethylamine $\left(0^{\circ} \mathrm{C}\right)$ was added to adjust the $\mathrm{pH}$ to $8.0-8.5$. The reaction mixture was kept at $0^{\circ} \mathrm{C}$ for $48 \mathrm{~h}$ and stirred. $50 \mathrm{ml}$ of $1 \mathrm{M}$ ammonium chloride and $1 \mathrm{M}$ ammonia solution was added to remove the unreacted azide. The final product was collected by suction filtration and washed sequentially with $0.1 \mathrm{M}$ hydrochloric acid, water and methanol to remove any unreacted starting material.

Resin characterization

Water regain. The method of Parrish [11] was used. 
Hydrogen ion capacity. Total acidic hydrogen content was determined by back-titration. A $0.2-\mathrm{g}$ sample of the resin in the acidic form was added to $10.0 \mathrm{ml}$ of $0.10 \mathrm{M}$ sodium hydroxide and the mixture was equilibrated for $2 \mathrm{~h}$ at room temperature with stirring. After filtration with suction, the excess of alkali was titrated with $0.10 \mathrm{M}$ hydrochloric acid.

Procedure for determination of acidity constants. Air-dried resin in the hydrogen form $(0.200 \mathrm{~g})$ was shaken in polyethylene bottles for $48 \mathrm{~h}$ with $2 \mathrm{M}$ potassium chloride containing different amounts of $0.10 \mathrm{M}$ sodium hydroxide at constant ionic strength of $0.1 \mathrm{M}$. The total volume of the solution was $25.0 \mathrm{ml}$.

\section{Metal ion uptake as a function of $\mathrm{pH}$}

A batch technique was used, the chelating functions always being in excess to the metal. Dry resin $(0.3 \mathrm{~g})$ was suspended with $50 \mathrm{ml}$ of $1.00 \times 10^{-3} \mathrm{M}$ solution of the cation perchlorate. The $\mathrm{pH}$ was adjusted by adding $0.1 \mathrm{M}$ perchloric acid or $0.1 \mathrm{M}$ sodium hydroxide. Suspensions were stirred for $48 \mathrm{~h}$ and then filtered. The concentrations of metal ions in the solution were determined spectrophotometrically.

The spectrophotometric methods used were as follows [12]: cuprizone [bis(cyclohexanone)oxalyldihydrazone] for copper, Nitroso-R salt (1nitroso-2-hydroxy-3,6-naphthalenedisulfonic acid, disodium salt) for cobalt, dimethylglyoxime for nickel, xylenol orange for zinc and 1,10-phenanthrolinium chloride for iron.

\section{Resin capacity and sorption isotherm}

The procedure used above to study the variation of metal ion uptake with $\mathrm{pH}$ was applied, except that $\mathrm{pH}$ was kept fixed at 5.5 for the duration of the equilibration and that the metal ion concentration varied for each trial.

\section{Concentration of trace metals}

For all column studies, a $90 \times 4-\mathrm{mm}$ column of the histidine-containing resin was used. For the recovery of trace metals, the sample was deionized water containing various amount of metal ion buffered to $\mathrm{pH}$ 6.0. Triplicate $250-\mathrm{ml}$ samples were passed through resin columns at a flow rate of $3 \mathrm{ml}$ $\mathrm{min}^{-1}$. After collection, the complexed metals were stripped from the column with $5 \mathrm{ml}$ of $2 \mathrm{M}$ hydrochloric acid or $2 \mathrm{M}$ hydrobromic acid. They were determined spectrophotometrically.

The effect of ligands on the recovery of the ions was examined for 250-ml portions of deionized water to which were added $1 \mathrm{mg} \mathrm{l}^{-1}$ of each metal ion and a large excess of the ligand under study.

\section{RESULTS AND DISCUSSION}

\section{Characterization of resin}

In order to verify the presence of histidine groups in the synthesized resin, the infrared spectra of the resin shown in Fig. 2 were obtained with $\mathrm{KBr}$ pellets after each step in the synthesis. The i.r. spectrum of the Amberlite 


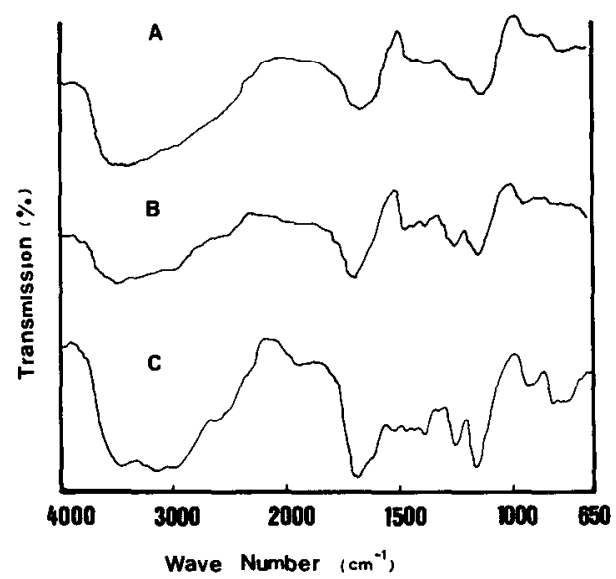

Fig. 2. Infrared spectra: (A) Amberlite IRC-50;(B) esterified product; (C) resin containing histidine groups.

IRC-50 showed bands at $3500-2500$ and $1670 \mathrm{~cm}^{-1}(-\mathrm{COOH})$, whereas the spectrum of the esterified product exhibited bands at 1700, 1250 and $1150 \mathrm{~cm}^{-1}$ (-COOR). The spectrum of the final product showed bands at $1530 \mathrm{~cm}^{-1}$ (imidazolium group).

Elemental analysis gave $51.35 \% \mathrm{C}, 7.3 \% \mathrm{H}, 2.2 \% \mathrm{~N}$ and $39.1 \% \mathrm{O}$. The content of $2.2 \%$ nitrogen means that each $1 \mathrm{~g}$ of resin contains $1.59 \mathrm{mmol}$ of nitrogen.

Table 2 shows the physical and chemical characteristics of the histidinecontaining resin. The acidity constants were obtained by the direct algebraic method from the titration curve. The $\mathrm{p} K_{\mathrm{a}}$ value of 5.8 is assigned to the imidazolium group, and is close to the value for the imidazolium group of the monomeric histidine [13].

\section{Metal ion uptake as a function of $\mathrm{pH}$}

The ex traction behavior of the resin toward various cations [ $\mathrm{Fe}(\mathrm{III}), \mathrm{Ni}(\mathrm{II})$, $\mathrm{Cu}(\mathrm{II}), \mathrm{Zn}(\mathrm{II}), \mathrm{Ag}(\mathrm{I}), \mathrm{Hg}(\mathrm{II})$, and $\mathrm{Au}(\mathrm{III})]$ was investigated in aqueous solution over the $\mathrm{pH}$ range $0-6$. The data from these experiments are presented in Fig. 3. Over this pH domain, alkali and alkaline earth metal ions were not extracted and therefore exhibit no affinity for the histidine function. Generally, the uptake of the other cations increased with $\mathrm{pH}$ and was quantitative over $\mathrm{pH} 5$ for the tested metals.

These data for the percent extracted vs. $\mathrm{pH}$ can be summarized in terms of the half-extraction $\mathrm{pH}\left(\mathrm{pH}_{1 / 2}\right)$. A comparison of the $\mathrm{pH}_{1 / 2}$ values (Table 3) with the available stability constants [9] for the corresponding histidine monomer shows quite good agreement; the order of the stability constants is $\mathrm{Fe}(\mathrm{III})>\mathrm{Cu}$ (II) $>\mathrm{Zn}$ (II) $>\mathrm{Ni}$ (II), while $\mathrm{Au}(\mathrm{III})>\mathrm{Hg}(\mathrm{II})>\mathrm{Ag}(\mathrm{I})$. Therefore, the $\mathrm{pH}_{1 / 2}$ values can be considered as a good indication of the affinity of the 
TABLE 2

Physical and chemical characterization of the histidine-containing resin

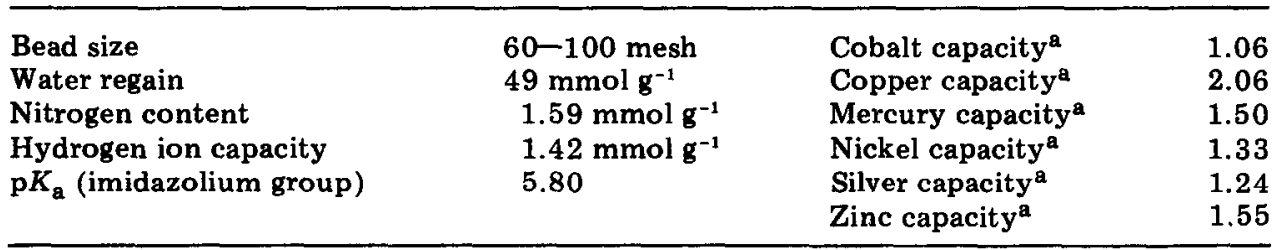

at $\mathrm{pH} 5.5$, all given as $\mathrm{mmol}^{-1}$.
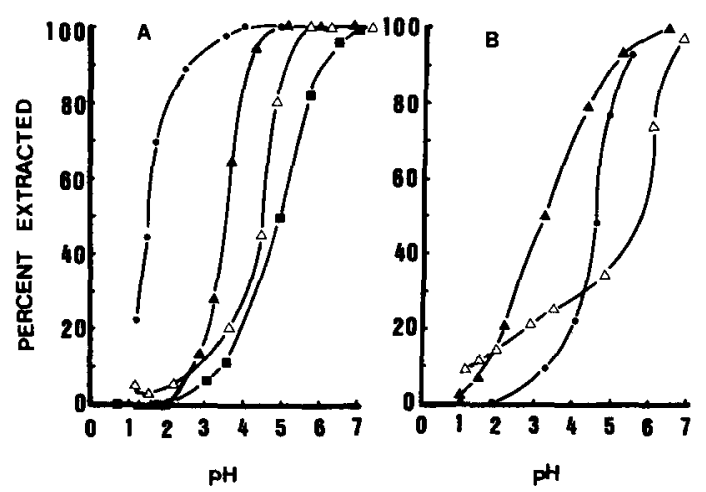

Fig. 3. Metal uptake as a function of pH. In $\mathrm{A}$ : (४) $\mathrm{Cu}(\mathrm{II}) ;(\bullet) \mathrm{Fe}(\mathrm{III}) ;(\bullet) \mathrm{Ni}(\mathrm{II}) ;(\Delta) \mathrm{Zn}(\mathrm{II})$.

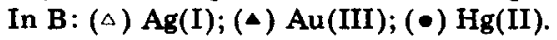

metal ion for the resin. There is a wide difference between the $\mathrm{pH}_{1 / 2}$ values of the different cations. Thus, the resin can be used for metal ion preconcentration and for selective separation and recovery, according to the equilibration $\mathrm{pH}$. The results indicate that all the cations under examination can be preconcentrated effectively at the natural $\mathrm{pH}$ of environmental water, i.e., without the previous addition of any $\mathrm{pH}$-adjusting reagents.

\section{Resin capacity and sorption isotherms}

The sorption isotherms of the resin were examined to establish the behavior of its chelating sites during saturation and its maximal capacity (Table 2). The results are plotted in Fig. 4. Some metals exhibit an uptake which exceeds the resin capacity as determined by the nitrogen content. This may be due to the chelating properties of the unreacted carboxylic acid of the polymer matrix.

\section{TABLE 3}

$\mathrm{pH}$ for $50 \%$ extraction $\left(\mathrm{pH}_{1 / 2}\right)$ of ions by the histidine-containing resin

\begin{tabular}{llllllll}
\hline Metal ion & $\mathrm{Ag}(\mathrm{I})$ & $\mathrm{Ni}(\mathrm{II})$ & $\mathrm{Cu}(\mathrm{II})$ & $\mathrm{Zn}(\mathrm{II})$ & $\mathrm{Hg}(\mathrm{II})$ & $\mathrm{Fe}(\mathrm{III})$ & $\mathrm{Au}(\mathrm{III})$ \\
$\mathrm{pH}_{1 / 2}$ & 5.7 & 5.0 & 3.6 & 4.5 & 4.6 & 1.5 & 3.2 \\
\hline
\end{tabular}




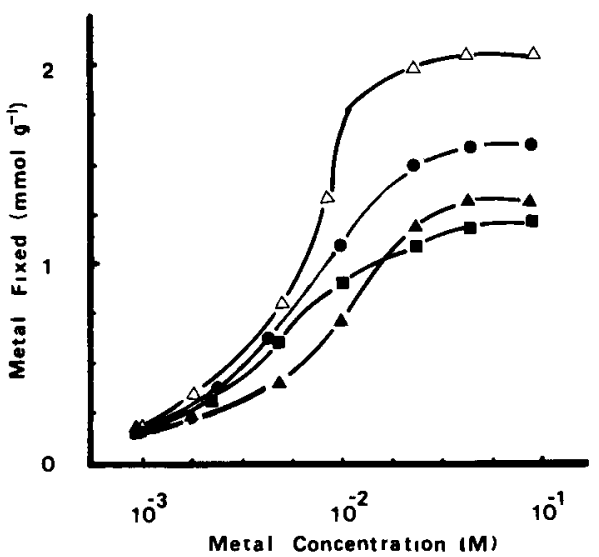

Fig. 4. Metal uptake as a function of metal concentration: ( $) ~ \mathrm{Ag}(\mathrm{I}) ;(\triangle) \mathrm{Cu}(\mathrm{II}) ;(\triangle) \mathrm{Ni}(\mathrm{II})$; $(\bullet) \mathrm{Zn}(\mathrm{II})$.

\section{Trace metal studies}

In recent years, there has been increasing concern over the health hazard caused by pollution of the environment by heavy metals and numerous procedures have been developed for the determination of these metals. Chelating ion-exchange resins of different types have proved beneficial for preconcentration [1]. To demonstrate the usefulness of the histidinecontaining resin for concentrating heavy metals and noble metals, the recovery of seven trace metals was tested for synthetic samples. The results (Table 4) showed excellent recovery for all.

The effects of complexing agents on the recoveries of $\mathrm{Fe}$ (III), $\mathrm{Cu}$ (II), $\mathrm{Hg}(\mathrm{II})$ and $\mathrm{Ag}(\mathrm{I})$ at $1 \mathrm{mg} \mathrm{l}^{-1}$ concentrations was studied by adding an excess

\section{TABLE 4}

Recovery of trace metals from aqueous media on the histidine-containing resin

\begin{tabular}{|c|c|c|c|c|c|c|c|}
\hline $\begin{array}{l}\text { Metal } \\
\text { ion }\end{array}$ & $\begin{array}{l}\text { Amount } \\
\text { added }^{\mathrm{a}} \\
(\mu \mathrm{mol})\end{array}$ & $\begin{array}{l}\text { Amount } \\
\text { found }{ }^{b} \\
(\mu \mathrm{mol})\end{array}$ & $\begin{array}{l}\text { Recovery } \\
(\%)\end{array}$ & $\begin{array}{l}\text { Metal } \\
\text { ion }\end{array}$ & $\begin{array}{l}\text { Amount } \\
\text { addeda }^{\text {a }} \\
(\mu \mathrm{mol})\end{array}$ & $\begin{array}{l}\text { Amount } \\
\text { found }^{b} \\
(\mu \mathrm{mol})\end{array}$ & $\begin{array}{l}\text { Recovery } \\
(\%)\end{array}$ \\
\hline \multirow[t]{2}{*}{$\operatorname{Ag}(I)$} & 5.0 & 4.75 & 95 & $\mathrm{Ni}(\mathrm{II})$ & 5.0 & 4.80 & 96 \\
\hline & 0.5 & 0.45 & 90 & & 0.5 & 0.46 & 93 \\
\hline \multirow[t]{2}{*}{$\mathrm{Cu}(\mathrm{II})$} & 5.0 & 4.90 & 98 & $\mathrm{Zn}(\mathrm{II})$ & 5.0 & 4.80 & 96 \\
\hline & 0.5 & 0.48 & 96 & & 0.5 & 0.47 & 94 \\
\hline \multirow[t]{2}{*}{$\mathrm{Fe}$ (III) } & 5.0 & 4.95 & 99 & $\mathrm{Au}(\mathrm{III})$ & 5.0 & 3.10 & 62 \\
\hline & 0.5 & 0.48 & 96 & & 0.5 & 0.35 & 70 \\
\hline \multirow[t]{2}{*}{$\mathrm{Hg}(\mathrm{II})$} & 5.0 & 5.00 & 100 & & 0.5 & $0.47^{\mathrm{c}}$ & 94 \\
\hline & 0.5 & 0.49 & 97 & & & & \\
\hline
\end{tabular}

a In $250 \mathrm{ml}$ of $\mathrm{pH} 6.0,0.1 \mathrm{M}$ hexamine buffer. ${ }^{b}$ Elution with $2 \mathrm{M} \mathrm{HCl}$, except where indicated. ${ }^{\mathrm{c}}$ Elution with $2 \mathrm{M} \mathrm{HBr}$. 


\section{TABLE 5}

Recoveries of trace metals in the presence of various ligands with the histidine-containing resin

\begin{tabular}{|c|c|c|c|c|c|}
\hline \multirow[t]{2}{*}{ Ligand } & \multirow{2}{*}{$\begin{array}{l}\text { Amount } \\
\text { added } \\
\left(\mathrm{mg} \mathrm{l}^{-1}\right)\end{array}$} & \multicolumn{4}{|c|}{ Recovery (\%) ${ }^{\mathbf{a}}$} \\
\hline & & $\mathrm{Fe}(\mathrm{III})$ & $\mathrm{Cu}(\mathrm{II})$ & $\mathrm{Hg}(\mathrm{II})$ & $\operatorname{Ag}(\mathbf{I})$ \\
\hline Sodium acetate & 60 & $98(6.1)$ & $98(6.2)$ & $100(4.9)$ & $95(6.5)$ \\
\hline $\mathrm{KH}_{2} \mathrm{PO}_{4}$ & 136 & $57(6.2)$ & $97(6.4)$ & $100(5.9)$ & $92(6.5)$ \\
\hline \multirow[t]{2}{*}{ Citric acid } & 210 & $46(3.5)$ & $98(6.0)$ & $100(4.5)$ & $89(6.3)$ \\
\hline & 2100 & $36(2.5)$ & - & $30(3.3)$ & - \\
\hline \multirow[t]{2}{*}{ Ammonium tartrate } & 185 & $84(4.4)$ & $75(6.1)$ & $100(4.1)$ & $81(6.7)$ \\
\hline & 1850 & $80(4.9)$ & - & $97(5.0)$ & $78(6.3)$ \\
\hline
\end{tabular}

a Metal ion present at the $1 \mathrm{mg} \mathrm{^{-1 }}$ level. The numbers in parentheses indicate the $\mathrm{pH}$ of the solution tested.

\section{TABLE 6}

Recovery of mercury $\left(140 \mu \mathrm{g} \mathrm{l}^{-1}\right)$ from binary mixtures with other metal ions in a sample volume of $250 \mathrm{ml}$

\begin{tabular}{llllllll}
\hline $\begin{array}{l}\text { Metal } \\
\text { ion }\end{array}$ & Me:Hga & $\begin{array}{l}\text { Hg found } \\
\left(\mu \mathrm{g} \mathrm{I}^{-1}\right)\end{array}$ & $\begin{array}{l}\text { Recovery } \\
(\%)\end{array}$ & $\begin{array}{l}\text { Metal } \\
\text { ion }\end{array}$ & $\mathrm{Me}: \mathrm{Hg}^{\mathrm{a}}$ & $\begin{array}{l}\mathrm{Hg} \\
\left(\mu \mathrm{g} \mathrm{I}^{-1}\right)\end{array}$ & $\begin{array}{l}\text { Recovery } \\
(\%)\end{array}$ \\
\hline $\mathrm{Ag}(\mathrm{I})$ & 10 & 131 & 94 & $\mathrm{~K}(\mathrm{I})$ & $10^{3}$ & 140 & 100 \\
$\mathrm{Cu}(\mathrm{II})$ & 10 & 119 & 85 & $\mathrm{Mn}(\mathrm{II})$ & 10 & 143 & 102 \\
$\mathrm{Cd}(\mathrm{II})$ & 10 & 139 & 99 & $\mathrm{Na}(\mathrm{I})$ & $10^{3}$ & 140 & 100 \\
$\mathrm{Co}(\mathrm{II})$ & 10 & 137 & 98 & $\mathrm{Ni}(\mathrm{II})$ & 10 & 136 & 97 \\
$\mathrm{Fe}(\mathrm{III})$ & 10 & 133 & 95 & $\mathrm{Zn}(\mathrm{II})$ & 10 & 137 & 98 \\
\hline
\end{tabular}

aMolar ratio.

of various ligands. As shown in Table 5, the recovery of mercury was almost unaffected by the ligands studied.

Because the results of Tables 4 and 5 showed that mercury could be recovered quantitatively and selectively, the recovery of mercury from binary synthetic mixtures was tested. The results given in Table 6 showed that there was little effect from other metal ions except copper(II) ion.

\section{Conclusion}

The results prove that the resin containing histidine groups has potential for the preconcentration of mercury from natural water or biological samples. Considerable work is still needed to increase the versatility of the preconcentration system by detailed studies of chemistries involved.

The financial support of this work by the National Science Council of the Republic of China is gratefully acknowledged. 


\section{REFERENCES}

1 A. Mizuike, Enrichment Techniques for Inorganic Trace Analysis, Springer-Verlag, Berlin, 1983.

2 C. J. Gray, Mechanism der Enzymkatalyse, Akademie Verlag, Berlin, 1976, pp. 83, 174 and 190.

3 B. Chance, R. W. Estabrook and T. Yonetani, Hemes and Hemoproteins, Academic Press, New York, 1966, pp. 64, 273 and 371.

$4 \mathrm{E}$. Antonini and M. Brunori, Hemoglobin and Myoglobin in their Reactions with Ligands, North-Holland Publ. Co., Amsterdam, 1971, pp. 23, 77, 88 and 349.

5 H. Rein, O. Ristau and K. Ruckpaul, Biochim. Biophys. Acta, 393 (1975) 373.

6 Ch. A. Feldt and G. T. Kekish, U.S. Patent 3047516 (1962); Chem. Abstr., 58 (1963) 1605 b; U.S. Patent 3234150 (1966); Chem. Abstr., 64 (1966) $17812 \mathrm{~g}$.

7 H. P. Gregor, P. Teyssie, G. K. Hoeshele, R. Feinland, M. Shida and A. Tsuk, J. Am. Chem. Soc., 87 (1965) 5525.

8 G. Manecke and R. Schlegel, Makromol. Chem., 177 (1976) 3191.

9 L. D. Pettit, Pure Appl. Chem., 56 (1984) 247.

10 Y. S. Klausner and M. Bodanszky, Synthesis, (1974) 549.

11 J. R. Parrish, J. Appl. Chem., 15 (1965) 280.

12 J. Fries and H. Getrost, Organic Reagents for Trace Analysis, E. Merck, Darmstadt, 1977.

13 L. D. Pettit and J. L. M. Swash, J. Chem. Soc., Dalton Trans., (1976) 588. 